\title{
Voluntary medical male circumcision versus
} religio-cultural circumcision and initiation rites: The case of Varemba of Mwenezi district in response to the prevention of human immunodeficiency virus and acquired immunodeficiency syndrome in Zimbabwe

\begin{tabular}{|c|c|}
\hline \multicolumn{2}{|c|}{ 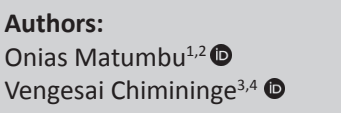 } \\
\hline \multicolumn{2}{|c|}{$\begin{array}{l}\text { Affiliations: } \\
{ }^{1} \text { Department of Religion, } \\
\text { Classics and Philosophy, } \\
\text { School of Religion and Social } \\
\text { Transformation, University of } \\
\text { Kwazulu-Natal, Durban, } \\
\text { South Africa }\end{array}$} \\
\hline \multicolumn{2}{|c|}{$\begin{array}{l}{ }^{2} \text { Department of Family } \\
\text { Religion and Moral } \\
\text { Education, Faculty of } \\
\text { Humanities, Morgan ZINTEC } \\
\text { College, Harare, Zimbabwe }\end{array}$} \\
\hline \multicolumn{2}{|c|}{$\begin{array}{l}{ }^{3} \text { Department of Politics, } \\
\text { Philosophy and Religion, } \\
\text { Lancaster University, } \\
\text { Lancaster, United Kingdom }\end{array}$} \\
\hline \multicolumn{2}{|c|}{$\begin{array}{l}{ }^{4} \text { Department of Religious } \\
\text { Studies and Philosophy, } \\
\text { Faculty of Arts, Culture and } \\
\text { Heritage Studies, Zimbabwe } \\
\text { Open University, Harare, } \\
\text { Zimbabwe }\end{array}$} \\
\hline \multicolumn{2}{|c|}{$\begin{array}{l}\text { Corresponding author: } \\
\text { Vengesai Chimininge, } \\
\text { vchimininge@gmail.com }\end{array}$} \\
\hline \multicolumn{2}{|c|}{$\begin{array}{l}\text { Dates: } \\
\text { Received: } 03 \text { June } 2018 \\
\text { Accepted: } 24 \text { May } 2019 \\
\text { Published: } 31 \text { Oct. } 2019\end{array}$} \\
\hline \multicolumn{2}{|l|}{ Read online: } \\
\hline 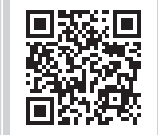 & $\begin{array}{l}\text { Scan this QR } \\
\text { code with your } \\
\text { smart phone or } \\
\text { mobile device } \\
\text { to read online. }\end{array}$ \\
\hline
\end{tabular}

Male circumcision has long been associated with religious or cultural rituals which bestow culturally valuable status. In some communities, circumcision is believed to provide concomitant access to economic and spiritual resources such as land and the ability to communicate with the ancestors. However, the recent promotion of voluntary medical male circumcision (VMMC) in 2009 as an additional dimension for reducing the spread of human immunodeficiency virus (HIV) was received with mixed feelings by different people in Zimbabwe. The resistance was more pronounced in those districts where male circumcision was a traditional norm. It is considering this background where this article examines whether VMMC and religio-cultural male circumcision are distant cousins or siamese twins. This is performed by taking a leaf from the Varemba of Mwenezi district in Zimbabwe. Data collection was performed between May and October 2017 using in-depth individual interviews within the context of the hermeneutics paradigm which emphasises the existence of multiple realities across time and culture. Our analysis of data shows that the Varemba of Mwenezi district does not believe in the efficacy of VMMC because it is void of the ritualistic cultural-spiritual dimension that usually accompanies male circumcision. The study recommended that VMMC should contextualise the cultural value to achieve set targets for HIV prevention.

Keywords: voluntary medical male circumcision; religio-cultural male circumcision; HIV and AIDS; Varemba; Zimbabwe.

\section{Introduction}

The new knowledge we possess today about the relationship between religious traditions and human immunodeficiency virus (HIV) and acquired immunodeficiency syndrome (AIDS) prescribes the urgency to look at the theme of HIV and AIDS from a new perspective that is harnessing and redefining useful traditional rites in the fight against the pandemic in Zimbabwe. This is so because some societies like Shangani in Chiredzi have opted to withdraw from HIV and AIDS programmes like voluntary counselling and testing that accuse their religion of fuelling the spread of the pandemic (Gono 2015:1). The thrust of this article therefore is to examine the attitude of the Varemba of Mwenezi district towards voluntary medical male circumcision (VMMC) as a strategy of fighting HIV and AIDS in Zimbabwe. The article is divided into three sections. The first part is a situation analysis of HIV and AIDS in Zimbabwe. This is followed by a brief literature review on male circumcision as a strategy of HIV and AIDS prevention. Lastly, the article presents and analyses the perceptions of the Varemba on VMMC in their society.

\section{Situation analysis of human immunodeficiency virus and acquired immunodeficiency syndrome in Zimbabwe}

Demographic statistics have shown the effects of the prevalence of HIV and AIDS in Zimbabwe. The Ministry of Health and Child Welfare (2008) established that out of 12 million people in Zimbabwe, 1.1 million were living with HIV and AIDS. Of the total population, 932000 were

How to cite this article: Matumbu, O. \& Chimininge, V., 2019, 'Voluntary medical male circumcision versus religio-cultural circumcision and initiation rites: The case of Varemba of Mwenezi district in response to the prevention of human immunodeficiency virus and acquired immunodeficiency syndrome in Zimbabwe', Theologia Viatorum 43(1), a3. https://doi.org/10.4102/TV.v43i1.3

Copyright: @ 2019. The Authors. Licensee: AOSIS. This work is licensed under the Creative Commons Attribution License. 
people in the age group of 15-49. Although HIV and AIDS prevalence between 1981 and 1987 increased from 12048 to 1438 456, it declined in 2008 to 914614 and a further decline to 911143 was noted in 2009 (HIV and AIDS in Zimbabwe 2017). The decline in HIV and AIDS prevalence during this period was attributed to different strategies implemented by the government, such as campaigns on the use and distribution of condoms, reduction in casual sex, campaigns on abstinence as well as increased counselling and testing (HIV and AIDS, Zimbabwe 2013). However, whilst there was a general decline of HIV and AIDS prevalence in the ages $15-49$, the prevalence rate in the age groups 15-29 continued to increase from $3.2 \%$ in 2009 to $3.3 \%$ in 2010 and $3.6 \%$ in 2015 (HIV and AIDS, Zimbabwe 2013). Some of the reasons suggested for the increase were high sexual risk behaviours and widespread unprotected sex.

\section{Male circumcision as a strategy to human immunodeficiency virus and acquired immunodeficiency syndrome prevention}

'Male circumcision has been identified in research as a protective cultural factor against HIV and AIDS' (Bailey et al. 2007:644-650; Moses 2009:629). About 400 ethnic groups in West Africa and in Muslim countries have been practising the ritual of circumcision for over 500 years (Bongaarts et al. 1989; Weiss et al. 2000:64). Research has established 'that circumcision might provide some degree of protection' to HIV (Moses 2009:629-634).

The view that circumcision may protect human beings against HIV infection was introduced and developed by Professor Valiere Alcena in North America (Morris 1999:630). The theory was promoted by Fink (1986:1167) who argued that the removal of the penis foreskin and the subsequent hardening of the lining known as Keratinisation of the penis reduce the chances of HIV penetration. The underside of the foreskin consists of thin Langerhans cells which are vulnerable to the HIV virus (Ford 2006). Thus, circumcision makes the penis to develop a new, hardened skin with fewer HIV target cells.

According to Auvert (2005:298) and Rennie, Muula and Westreich (2007:357), 'trials [carried out] in South Africa, Kenya and Uganda prove that male circumcision' was effective in reducing infection. Welbourne and Hoare (2008) concur that these findings substantiate the fact that circumcision provides some protection against the HIV virus. Based on these findings, the World Health Organization (WHO) and the Joint United Nations Programme on HIV / AIDS (UNAIDS) transformed 'a cultural practice into a [preventive] public health strategy (Moses 2009:631)'. The suggestion was 'that male circumcision [could] reduce' heterosexual transmission of HIV and AIDS 'by 60\%' (Van Houten 2007:168). Therefore, countries were urged to practise it in medical institutions through VMMC (WHO/ UNAIDS 2015).
However, according to recent statistics on HIV and AIDS, Zimbabwe has the poorest coverage rate on circumcision '[d]espite [...] being [listed as] [one of] UNAIDS' priority [countries] for the scale up of [V]oluntary [M]edical [M]ale [C] ircumcision [...] [that was] listed [on] the country's National Combination Prevention Strategy' (Avert n.d.; HIV and AIDS in Zimbabwe 2017). 'By 2018, Zimbabwe aims to reach 1.3 million men [who would have undergone] VMMC (80\% of [thirteen to twenty-nine-year] olds). As of 2016, it [has reached] $46.3 \%$ of [the] target group' (Avert n.d.). It was surprising to note that HIV and AIDS prevalence is higher among men who are circumcised, $14 \%$ higher than those who are not $(12 \%)$. Recent statistics show that Zimbabwe has the fifth highest HIV prevalence in sub-Saharan Africa, 14.7\%. Approximately 1.4 million people are living with HIV and AIDS, including 77000 children (HIV and AIDS in Zimbabwe 2017; Moyo 2017). The findings obtained from these studies suggest that circumcision on its own as an effective strategy is a conjecture. At individual level, circumcision does not prevent HIV transmission reliably (Mattson 2005:187). Men who tend to have surgical immunity after circumcision increase their risk of contracting the HIV virus.

The skewed statistics on HIV and AIDS in Zimbabwe shows that circumcision on its own is not enough as a prevention strategy against HIV. Hence, there is need for behaviour change after individuals have gone through voluntary male circumcision. Auvert (2005:79) opines that the risk of HIV transmission remains real among circumcised men who could increase their exposure by engaging in unprotected sex and risky behaviour. Circumcised persons may become promiscuous having learnt the benefits of circumcision in reducing the chances of contracting HIV and AIDS.

Another observation obtained from the statistics is that positive behaviour change after circumcision is crucial in militating against the spread of HIV and AIDS. Gray et al. (2007:558-659) observed that cultural circumcision and initiation have been useful in most African countries in preventing HIV and AIDS. This study hinges upon the view that religion and the strong adherence to religious principles could protect people against HIV and AIDS transmission (Agha et al. 2006:553). 'Circumcision [on its own] cannot prevent the spread of HIV' (Tarimo et al. 2012). After being circumcised, men need to go through initiation where they receive instruction necessary to mould their behaviours and assist them to develop positive and less risky attitudes towards issues of sex and sexuality.

Circumcision is a religious-cultural practice used in scientific circles to pursue the problem of HIV and AIDS in Zimbabwe. The adoption of traditional male circumcision for use by medical institutions left out the initiation aspect and all the ritual elements. The fact that the ritual has been performed from time immemorial means that it is of religious significance and is influential to those who practise it. Voluntary medical male circumcision is non-religious, non-obligatory and nothing compels the individual to undergo the ritual. 'It has become increasingly important to focus research [on] the 
current role of initiation [rituals] and [their effects on] sexual behaviour and risk knowledge of the [youths]' (Malisha, Maharaj \& Rogan 2008).

\section{Varemba circumcision and initiation rite}

Varemba or Vamwenye are the Shona speaking ethnic group indigenous to Zimbabwe and South Africa. According to Parfitt (2002:42-43), other Varemba minority groups are found in Mozambique and Malawi. Ethnic groups in Zimbabwe such as the Tonga, the Varemba, the Shangani and the Yao migrants perform initiation rites as puberty rituals of transition into adulthood (Sibanda 2013:5). Nevertheless, the religious beliefs and practices of the Varemba people are similar to those of the Jews and Muslims (Le Roux 2003:221). 'According to [Varemba] tradition, their male ancestors were Jews who left Judea about 2500 years ago and settled in [Yemen]' (Wikipedia n.d.:n.p). 'Most [Varemba people] are members of the Christian churches with some being Muslims' (Parfitt 2002:43; Wikipedia n.d.:n.p).

The Varemba are predominantly found in Mberengwa districts of the Midlands province and other parts of Masvingo, for example Gutu, Chiredzi, Neshuro, Hwedza and Buhera (Mandivenga 1989:98). The Varemba tribe has a long history of observing initiation of boys into manhood through practising traditional male circumcision among all their men folk. The Varemba circumcision and initiation rites are the footstool of enriching lessons that equip the young men to be conscious about their lives.

\section{Origin of the Varemba circumcision and initiation rite}

The origin of the circumcision rite is controversial, but to some extent, its origin is attached to issues of sex and sexuality. The Varemba people are believed to have acquired it from the Jews and Arabs to whom their ancestry and history is traced (Parfitt 2002:43). Circumcision is also interpreted to have '[originated] from [...] fertility [rites] as a sacrifice to the gods in exchange for good harvest' (Dunsmuir \& Gordon 1999:7; WHO 2009:15). In the Bungoma Districts of Kenya, circumcision takes place after harvest (Bailey \& Egesah 2006:650). 'Among the [Balande] in Guinea-Bissau and Senegal circumcision ceremonies are [...] performed in the rice fields [as] reverence to [the] ancestors and the [earth]' (Niang \& Boiro 2007:26; WHO 2009:15). Circumcision is also seen as a distinguishing feature between God's children and those who are not (Popovsky 2010).

Traditional male circumcision [is practised] as a rite of passage [and it] is performed in pre-pubertal boys, [adolescents] or adults. The age [at which] circumcision [is practised] varies [from] country [to country as well as] ethnicity, ranging from [six] years [for example] in Senegal and Indonesia[,] to [thirty-five] years [in] Zambia. (Niang \& Boiro 2007:26; WHO 2009:11)

In Zimbabwe, the Shangani circumcise their youth at the ages between 13 and 17, whilst the Varemba circumcise from the age of 12 (Evans 2015; Sibanda 2013:3). The age group 15-29 is the most vulnerable group for new HIV and AIDS infection in Zimbabwe (HIV and AIDS, Zimbabwe 2013). The Varemba and the Bukusu in Kenya circumcise their youth every year, whilst in South Africa, it is performed twice, but the Balante in Guinea-Bissau circumcise after every 4-6 years (Bailey \& Egesah 2006:33, Niang \& Boiro 2007:30). In most cases, the circumcision rituals coincide with physical maturation and that makes it very useful in the growth of the young people. Bailey and Egesah (2006:649) established that about ' $47.7 \%$ of the young men' in Kenya become sexually active before they are circumcised. Sexual debut was estimated to be at the average of 14-15 years in those groups studied for traditional circumcision (Bailey \& Egesah 2006:567-574).

\section{Meanings attached to the initiation ritual}

The circumcision ritual has meanings both at individual and social and also at individual level as noted among the Varemba people who believe that the circumcision ritual gives identity to the person (Sibanda 2013:6). It distinguishes those that belong to the Varemba culture and those that do not. Generally, circumcision is equated to health and cleanliness among traditionally circumcising and noncircumcising groups (Taljaard 2003:321). Among the Wolof of Senegal, circumcision is related to cleanliness and the metaphor 'to wash hands' is used to signify male circumcision and 'the child who has clean hands can eat with adults', meaning that he can sit and share ideas with elders (Niang \& Boiro 2007:24).

Belief in the disease protective role of male circumcision has been widespread among traditional healers (Green et al. 1993:182-183). Male circumcision is believed to have a protective effect against sexually transmitted infections by preventing the tearing of the foreskin and hence reducing the chances of contracting diseases (Ngalande et al. 2006:384; Taljaard et al. 2003:317). Some possible links between circumcision and HIV control have been drawn from the 'Balante [tribe of] Guinea-Bissau [who had a belief that] circumcision [can] protect [people against a] terrible disease called Pusoonu [...][that had] symptoms [...] similar to those of [HIV and] AIDS' (Niang \& Boiro 2007:28; WHO 2009:13). 'However, [contrary to that, studies in some countries for example] Nigeria [...] do not [presume] disease protection as a reason [for circumcision]' (Caldwell et al. 1997; WHO 2009:13). The Varemba people do not practise circumcision primarily for health reasons or as a measure to control diseases, but their reasons are purely cultural (Evans 2015:266-279).

At socio-cultural level, circumcision is of 'significance [to most] traditionally circumcising communities because being circumcised is the only way of attaining manhood' (WHO 2009:14). Among the Varemba people, an individual who is not circumcised is considered young and is not held accountable for his actions but his parents (Evans 2015:267). 'In Xhosa culture, [...] when a boy is not able to distinguish 
[between what] is right [or] wrong, [he is not held] responsible for [his actions]' (Vincent 2008a:431-446; WHO 2009:14). Women deny proposals from uncircumcised individuals because they are considered young to start a family. Uncircumcised individuals 'are discriminated against in [many] ways, for example [they are] given menial tasks, [...] called names [and rebuked for any trivial offences]' (Meissner \& Buso 2007:372; WHO 2009:14). The boys who participate in social aspects of life are those that are circumcised. In Kenya, among the Masai and the Bukusu people, circumcised '[men] become warriors [...] and [they] are referred to as elders [once] their children [are] circumcised' (Marck 1997:338; WHO 2009:14). Male circumcision is seen as a condition of attaining full status in the society, for example among the Meru in Kenya and Guinea-Bissau and Senegal (Niang \& Boiro 2007:29).

\section{Features of the initiation rite}

Scholars like Van Gennep (1909) distinguished three phases of the circumcision rites such as preparation, seclusion and reintegration of ritual participants.

Preparation involves the initiate preparing his foreskin for easy retraction during circumcision. Some ethnic groups slaughter animals for sacrificial purposes (Bailey \& Egesah 2006:650). Some prepare extensive feasts a night before the ritual (Evans 2015:268). It was observed in this study that the Varemba performed ritual bathes, to dedicate the initiate for spiritual protection.

Seclusion of the initiates constitutes the most important part of the circumcision ritual. Time of seclusion varies from 2 weeks to 3 months, depending on the meaning attached to the ritual practice. The Varemba people go up to 3 months in the bush during seclusion. In Tanzania, traditional circumcisers perform circumcision but there is no seclusion after that (WHO 2006). The period spent in seclusion after circumcision can be viewed as a period of 'incubation' where new attitudes and behaviours are inculcated (Niang \& Boiro 2007:27). It is the period when cultural knowledge is transmitted to the initiates (WHO 2006). During seclusion, the initiates are exposed to hardships and ordeals that are meant to toughen them in preparation for future life. The initiates often experience bullying, humiliation and starvation.

Education on issues of sex and sexuality constitute part of the education curriculum during seclusion, but it is not necessarily a general component of all initiation rituals (Niang \& Boiro 2007:25). For example, in Zambia, the essence of circumcision is to develop boys' character but there is no sex education in the teaching after circumcision. In Malawi, male circumcision is followed by education on matters of sexuality, hygiene and good behaviour (Ngalande et al. 2006:383). In Zimbabwe, among the Varemba people, circumcision is followed by education on sex and sexuality issues and different moral values (Sibanda 2013:5). However, studies from South Africa in the Eastern Cape have shown that traditional education component of initiation ritual has waned (Vincent 2008b:440). Generally, messages transmitted to the initiates during seclusion focus on sexual reserve and control, sexual education and guidance on marriage and relationships.

After the period of seclusion, festivals to welcome the initiates accompany reintegration. Among the Varemba in Zimbabwe, reintegration takes 1 week, and it is accompanied by festivals and the offering of gifts (Evans 2015:267).

Among the Balante in Guinea-Bissau and Senegal, [...] reintegration takes six days and [it is accompanied by] ritual bathes and [...] giving [of] new [names to the initiates]. [...] [The initiates] are not allowed to have sex with their wives [for] the first six days [after initiation so that they demonstrate the newly learnt resistance to sexual attraction]. (Niang \& Boiro 2007:26; WHO 2009:16)

The Bukusu in Southern Kenya burnt sleeping mats and spend nights seating around a very big fire where they are joined by young women (Marck 1997:339).

There are variances on the rite of circumcision concerning specific procedures. The Varemba people circumcise the initiates traditionally, and they disregard initiates who get medical circumcision and they do not want to mix the two (Evans 2015). Some ethnic groups perform circumcision in a clinical setting before or after performing traditional initiation. Initiates in some groups in Botswana receive hospital circumcision, then after that, they go for an initiation ceremony at a traditional school (Marck 1997:351). Therefore, there is a strong feeling 'that medical male circumcision should be linked [with] traditional initiation' (Kebaabetswe et al. 2003; WHO 2009:17). The Yao of Malawi perform traditional initiation in their communities after the young people receive circumcision at medical centres (Ngalande et al. 2006:379). Circumcision could be performed at health centres with initiation performed in the bush thereafter (Niang \& Boiro 2007:27). The Sotho and the Pedi tribes in South Africa practise traditional fragmentation of circumcision and initiation, where initiation takes place several years after medical circumcision (Marck 1997:340). Most of the people in the Varemba tribe are not happy with this kind of fragmentation of the puberty ritual; they prefer circumcision to be performed at the same time with initiation because the two have some traditional influence valuable to the initiates (Evans 2015:268).

\section{Perceptions of the Varemba about the role of circumcision and initiation ritual on human immunodeficiency virus and acquired immunodeficiency syndrome}

Most participants for this research argued that the strength of initiation ritual in moulding behaviours towards the prevention of HIV and AIDS lies in its recurrence. Participants who saw the initiation ceremony being beneficial pointed out that the ritual is repeated every year with similar processes, 
so it has the potential of emphasising key HIV and AIDS messages to the youth and the general population. Human immunodeficiency virus and AIDS messages are passed on to the next generation together with the Varemba traditional culture. The way their culture is preserved is the way important messages about HIV and AIDS could be preserved.

Boyde (participant, aged 23) revealed that the Varemba initiation ritual could be a good platform to spread the message about HIV and AIDS. Awareness campaigns can be held at the initiation camps and during ceremonies. The traditional education curriculum could be fused with absolute messages about HIV and AIDS prevention. Cherry (participant, aged 31) affirms that the initiation leaders, Mukanga and Vadzabhi, could be used as resource persons to teach the initiates issues on HIV and AIDS. They are respected people in society that could make their lessons about HIV and AIDS acceptable.

However, some traditional leaders had a different perspective about providing lessons to the initiates from the non-Varemba groups. The reasons provided were the desire by these cultural leaders to preserve their culture that was under the threat of modernisation whose aim was to culturally uproot the Africans consciously or unconsciously and immerse them in Western culture (Makuvaza 1996:373). Takavarasha (village headman) retorts that they do not want to be used by those people whose aim is to destroy their cultural practices in the guise that they are bringing civilisation and enlightenment. This could be the reason why the Varemba people were not comfortable with VMMC because participants like Huni (aged 61) alleged that it produces cowards who run away from traditional culture to seek refuge in modernity, where circumcision without initiation is not enough to produce a real man.

Most of the ritual leaders showed that they do not have problems including in their initiation curriculum the subject of HIV and AIDS, but they indicated that what they do not want is to train cowards who run from traditional culture to seek refuge in modernity, where circumcision is not enough to produce a real man. Michael (Vadzabhi, aged 67) stipulated that they do not want to be drawn into training youths from medical institutions and come out half-baked. The responses from most participants give the implication that the Varemba doubt the efficacy of VMMC because it does not expose the patients to lifetime lessons.

\section{Perceptions of the Varemba on the uptake of voluntary medical male circumcision}

Most ritual elders pointed out that they are reluctant to take up voluntary medical circumcision because it does not meet their cultural expectations. Initiation transforms the individual into becoming man. Mombera Joseph (aged 17, participant from Matibi) acknowledged that individuals remain shuvuro after going through VMMC and they are good examples of cowards who run away from traditional circumcision in fear of pain. They would remain in the state of boys, who are looked down upon by their peers, who are laughed at and who are not trusted by anyone in society. Mombera claimed that such individuals are not equipped with adequate knowledge that is relevant to protect themselves from diseases.

Some participants indicated that the Varemba initiation ritual has prohibitions, which protects initiates from being vulnerable to sexually transmitted infections. It is a prerequisite that one who goes through the initiatory ritual should not mix or get into contact with women up to a period of 1 month after initiation. Jacob (participant, aged 15) noted that with hospital circumcision, meeting with women is not avoidable because women are involved in circumcision at medical centres.

The men from the Varemba culture who received voluntary circumcision pointed that behaviour change after circumcision is the individuals' responsibility. No strategies are in place so far to enforce further restrictive avoidance strategies. Tendai Gonese (aged 19) acknowledges that VMMC is not imperative; it has no mechanisms to make it obligatory for members to change behaviours.

There are social cultural factors, which impede the uptake of VMMC. 'Zimbabwe [is recorded to have] the poorest VMMC coverage [...] in Sub- Saharan Africa' besides being listed as 'one of the [UNAIDS] priority countries for the scale up of [VMMC]' (Avrt n.d:n.p.). According to statistics from HIV and AIDS in Zimbabwe (2017), Zimbabwe's target for 2018 aimed at 1.3 million men to be circumcised, but by 2016, it had managed to achieve $46.3 \%$ of that target. Religious factors could have a contribution towards the low uptake of VMMC although other reasons like fear of pain and fear of being tested for HIV first. The Varemba people feel that their cultural traditions are under threat and they discourage their members from attaining medical circumcision.

\section{Implications of the Varemba circumcision and initiation ritual on behaviour change, human immunodeficiency virus and acquired immunodeficiency syndrome prevention}

Most people of the Varemba culture who participated in this research did not accept that they perform the ritual to prevent HIV and AIDS but the performances are purely cultural and religious. The discussion focuses on the role of the Varemba initiation ritual in the prevention of HIV and AIDS transmitted through heterosexual relations. The Varemba people do not have any primary intention of having the ritual influence the exterior world (outside them) or outside their own experiences that is the reason why their initiation ritual is closed to outsiders. According to Robertson Smith, some unconscious forces shape behaviour (Bell 2009). The implication is that it is not in all cases when believers are conscious of the main purpose of a ritual, the significance of a ritual could be different from what the believers believe. 
In the analysis of taboo, Sigmund Freud notes that the ritual is used to control internal psychic conflicts (Spinelli 1989: 34-38). The view that ritual exists in the individual psyche determines how ritual can influence individual behaviour towards HIV and AIDS mitigation processes, because behaviour change is intrinsically motivated. The Varemba initiation ritual is composed of both the manifest and latent functions, which should be realised to determine the efficacy of the ritual in HIV and AIDS prevention. Put in the context of HIV and AIDS the Varemba initiation ritual, besides having manifest functions, has latent functions which are buried underneath; such functions if exposed could be useful in the prevention of HIV and AIDS. In Freud's view, the unconscious motive is the root for ritual but it guides the internal development of the individual, ritual thinking brings meaning to human beings in the face of emptiness and contradictions in their experiences (Spinelli 1989:35).

The Varemba circumcision and initiation ritual is very significant in imparting a sense of unity in the people after the ritual. This could be useful in bringing them together in the fight against HIV and AIDS. Moyo (participant, aged 21) points out that Makudo ndimamwe musi wenjodzi anoonerana, meaning that Baboons are the same, and on the day of trouble, they fight for each other. This has emphasis on unity of the people when reacting against issues causing despondency to the society. The implication is that the Varemba initiation ritual instils a sense of communal solidarity towards problems that affect the community. Collective solidarity is achieved in the initiation ritual through a mechanism which Durkheim calls collective effervescence (Durkheim 1912:52-53). This refers to the excitement that people produce during the enactment of a ritual. The effect of collective effervescence is that it contributes to the emergence of collective conscience that brings social solidarity as people participate in collective veneration of the sacred which binds the community together and brings meaning to individuals (Greenwald 1973:157-158). Therefore, collective performance can generate emotions that could transform individual psyches and channel them towards collective conscience (Pickering 1984). The collective excitement induced by rituals 'harness[es] people's passions to [maintain] order [in] society (Shilling \& Mellor 1998:196)' (Thorlindsson \& Bernburg 2004). Through this solidarity the Varemba people have shared values, they develop a sense of 'no one owns it, it's for us all', kind of mentality. In the context of HIV and AIDS, the kind of mentality is useful in helping those individuals who are affected and infected by the disease. Chandiwana (initiate aged 30) reinforced: Chawana umwe hachisekanwi, seka urema wafa, meaning one's problem should not induce laughter because tomorrow you will be in a similar problem. The kind of unity instilled by the ritual act makes it possible for the people to come together and help each other in the struggle against HIV and AIDS.

The Varemba initiation ritual encourages youths to delay in sexual debut and this according to the Varemba initiation (Koyana 1980) is a gateway to legitimate marriage and sex. It is crucial to note that the initiation does not only involve circumcision, but has an accompanying process of instruction which has an educational feature 'aimed at building certain character traits [like chastity, fortitude and] forbearance' necessary for the prevention of HIV and AIDS (Vincent 2008b:436). In that 'framework, sexual [behaviour] is shaped by personal experiences and influenced by cultural assumptions, expectations, roles and practices (Boyce et al. 2007:26)' (Skinner et al. 2013). '[Culture determines] not only which sexual relations are acceptable, but also at what times and under what circumstances are they appropriate' (Nkwi 2005:2135).

This study established that the Varemba initiates are taught how to make right choices at the appropriate time and are not encouraged to marry before they have gone through puberty rituals. Marriage is permissible when one has gone through initiation. In the Varemba culture, those recently initiated are not allowed to marry or engage in sexual relations up to a period of a year. Those who are married are not allowed to have sex up to 1 month. The practice could protect individuals from early exposure to sexually transmitted infections. This is contrary to other ethnic groups, for example the Nyau initiates of Zambia and Kikuyu of Kenya 'are encouraged to have sex soon after the [initiation] ceremony' to prove their learnt sexual prowess (Niang \& Boiro 2007:25; Skinner et al. 2013).

Among the Varemba of Mwenezi, there is clear evidence that some participants changed their behaviour after going through initiation, to pursue safe sex habits. Gonzo (aged 58), from Rinnete village, confirmed that his son changed his attitude towards sex after initiation. The conditions outlined encouraged the initiates to delay marriage and sex. Those not yet gone through initiation would maintain primary virginity, which is virginity for one who has never engaged in sex before. The married people who attended the initiation ritual having had engaged in sexual relations were forced into secondary virginity. After initiation, they were forbidden to engage in sexual relations up to a period of a month. Such ideas could encourage the initiates to have delayed sexual debut that could be necessary in delaying risky chances of being exposed to contracting the HIV virus. Studies have shown that vulnerability to HIV and AIDS risk increases with early sexual debut (Ghebremichael, Larsen \& Paintsil 2009:574; Hallett et al. 2007:5). An early onset of sexual activity, in or outside marriage put the individual at risk 'by extending the period of potential exposure to sexually transmitted pathogens [and immaturity] of the reproductive organs further [enhances the chances of the] individual's biological susceptibility' (Ghebremichael et al. 2009:576). Culture helps to determine the sexual relations that are acceptable and not (Nkwi 2005:2135). Mhosva Regedzai (aged 82, from Nikita) confirms that the initiates are forbidden to have sex for several months after initiation. If they intend to have sex, they are encouraged to get married. Therefore, sex education obtained during the Varemba initiation rituals is a useful tool for effective HIV and AIDS prevention because it encourages late sexual debut. 
Mturi and Hennink (2005)'s research on the initiation schools in South Africa concluded that the schools do not educate participants about safe sex [and] the dangers of HIV and AIDS, and may encourage risky sexual behaviour' (Malisha et al. 2008). These views only help to understand that the initiation schools' curriculum about issues of HIV and AIDS is not manifest but latent. The Varemba initiation school does not discuss issues of HIV and AIDS explicitly and it is not their agenda to discuss such issues. Nevertheless, they provide lessons that are relevant towards change of behaviour in the youths whose benefit is lowering the risk of contracting HIV and AIDS and other sexually transmitted infections.

A study of '38 countries in Sub Saharan Africa [meant] to compare Muslims in the population against the confirmed rate of HIV prevalence, found [that] Muslims in national population correlates with lower HIV prevalence' (Gray 2004:1753). Gray notes that most Muslims circumcise and they appear to engage in less risky sexual behaviours. The Varemba's Islamic link has a bearing in understanding the effectiveness of strong adherence to some cultural practices in HIV and AIDS prevention. As in Islamic communities there is less risky behaviour, the perceived link helps to understand the Varemba initiation ritual as effective. 'Male circumcision has been identified as protective cultural factor' (Auvert et al. 2005; Moses 2009). Prevalence of HIV and AIDS in African societies which traditionally circumcise has been discovered to be low particularly West Africa and Muslim countries (Weiss et al. 2000:2366) ' [D] ifferences in circumcision status [may help] to explain discrepancies in HIV prevalence' (Halperin \& Bailey 1990:1813-1814). It is not circumcision only which matters, but circumcision coupled with initiation that makes the Varemba people distinct.

The impact of the Varemba circumcision and initiation ritual on HIV and AIDS prevention can be observed on statistics about the prevalence of HIV and AIDS in Zimbabwe. Skewed statistics on HIV and AIDS in Zimbabwe show the need for behaviour change after individuals have gone through voluntary circumcision. It is of concern to notice that whilst the country is promoting circumcision as a measure to militate against the spread of HIV and AIDS, the prevalence rate in the circumcised population is increasing. Some of the reasons for the twisted statistics could be in line with what the research gathered in the field survey, which points to uninformed risky compensation behaviours. According to Doyle (2005), there is a need to work more directly on aspects of behaviour change in all ages and develop new cultural markers. Circumcised persons may become promiscuous having learnt the benefits of circumcision in reducing chances of getting HIV and AIDS.

The statistics could also mean that some groups of people do not accept medical circumcision which is why the coverage rate has been poor. Parirenyatwa, former minister of Health and Child Care in Zimbabwe, made a similar observation at the launch of VMMC in Marondera: 'the uptake of male circumcision is still very low in the country although the service is offered for free at government institutions'
(Taruvinga 2015:18). Most of the Varemba participants in this research in Mwenezi show that they were against medical circumcision.

However, traditional surgical practices have been identified as potential sources of HIV infection especially when performed in a group of people (Feldman 1990:47). '[I]f [...] serial use of [unsterilised] equipment features prominently' it may well put the initiates at risk of HIV (Ajuwon et al. 1995:380). During the Varemba initiation ritual, the Nyamukanga uses one knife, which they rinse in cold water after using it on each initiate. According to Ajuwon et al. (1995:382), the process of using one knife during circumcision puts the initiates at the risk of contracting HIV. An unsterilised knife subsequently exposes initiates to the bodily fluids of the previous initiate (Hardy 1987:101). The ritual leaders may spread the HIV virus if they are infected and have open wounds (Feldman 1990:52). The findings of these researches should not necessarily 'be construed as representative of [what transpires] in SubSaharan Africa'. Researchers have not established data that traditional surgical tools are vectors of transmission of HIV (Ajuwon et al. 1995:383-384). Packard and Epstein (1991:776) argue that a small number of initiates underwent incisions sequentially. In the case of Varemba initiation ritual, Chikwaya Mombe (aged 21, from Matibi) pointed out that not more than three initiates are circumcised at each interval, in the morning, afternoon and in the evening. There is significant time lapse between initiates that makes transmission through unsterilised object very unlikely because the virus does not survive long after it has been exposed (Ajuwon et al. 1995:382). Based on the responses of Gore Hukwe (aged 26, participant from Ndambi Village under chief Negare), during the Varemba initiation ritual there is considerable time lapse for treating the wound and washing the knife before the next initiate is circumcised. Gausset (2001) argues that most incisions are performed on adolescents who have lower prevalence of HIV and AIDS. Razor blades for use during shaving seemed affordable and accessible because each initiate could manage to bring one for use during the Varemba initiation ritual. According to Brightman (1995:520), the initiation practice has low potency towards transmission of HIV virus and therefore has an insignificant contribution towards the spread of HIV virus. Evidence gathered from the field shows that the Varemba ritual elders and the initiates are aware of the risks of spreading HIV and AIDS and each one of them is encouraged to bring his razor blade, for use in shaving the head and the pubic hairs.

The ordeals that the Varemba initiates go through have a positive contribution towards instilling positive and less risky behaviours in the youth. Asamoah (2001) laments the moral laxity of youth, and he thinks that the vulnerability of the youths to HIV and AIDS lies in their inability to control their sexual drive. Culture is responsible for socialising the youth and imparts them with requisites of humanness (unhu/ubuntu). Ntseane (2004:4) notes, 'sex is culturally 
regulated, and accepted types of sexual behaviour are learnt through [socialisation]'. Through song and dance, the youth are furnished with sexual advice and instruction expected of them by the society. The Varemba initiation ritual offers a strategy and an opportunity of re-engagement and dialogue 'with religious and ethnic groups in HIV [and AIDS] prevention' (Pelzer et al. 2007:660).

Researchers have a tendency of focusing on biological strategies for HIV and AIDS prevention. According to Granich and Mermin (2001), most discussions on issues of HIV and AIDS focus on biological interventions as the primary key towards HIV transmission (Granich \& Mermin, 2001). Nonetheless, such discussions circumvent the behavioural factors that have acted as impediments towards successful strategies. Granich and Mermin (2001) argue that biological technologies are at the top of the charts as treatment and prevention strategies, for example the use of highly active antiretroviral drugs and the use of condoms. All these require behaviour change. Kippax et al. (2011:394) note that AIDS is a social disease, its causes, consequences and human responses to it are deeply embedded in socio-cultural processes. The Varemba initiation ritual could be a valuable addition to the basket of strategies towards prevention of HIV and AIDS because it is culturally appropriate and locally relevant by targeting a specific group of people making them cognisant of their social context. The ritual strategy could have an idea over the type of behaviours to be changed for successful action.

\section{Conclusion}

The conclusion that can be drawn in this article is that VMMC and the Varemba circumcision and initiation rites should complement each other in fighting and reducing HIV and AIDS prevalence in the community under study. This is shown by the fact that the strength of the Varemba initiation ritual in moulding positive behaviours towards HIV and AIDS lies in that it is not voluntary and solitary but obligatory and a group phenomenon. The divine sanctifies the behaviours of the youth and makes it imperative for everyone to accept and follow the moral virtues of the society without questioning. Voluntary medical male circumcision is solitary and intentional; it removes the individual from the social, cultural and public domain, which stands as witness to the new person's status in the community. The Varemba initiation ritual is viewed as an event where the community is engaged in the processes which are transformative to the youth, and which provide transition to health. It provides vigorous lessons, which equip the initiate with skills of reflection and adjustment towards his behaviour. There is always public opinion over one's behaviour. The Varemba community of Mwenezi agree in principle that anyone who violates sex and marriage regulations is treated as an outcast and such a person should be beaten severely and mortified in public. This is why they believe that the youths need a public eye to verify, certify and acclaim their entry into puberty. The public celebrations are therefore necessary in strengthening the bond of the community.

\section{Acknowledgements}

The author would like to thank Mr Tomu Adam who happened to be the link person and key informant during the research and data gathering.

\section{Competing interests}

The authors declare that they have no financial or personal relationships that may have inappropriately influenced them in writing this article.

\section{Authors' contributions}

O.M. was very instrumental in the conceptualisation of idea, data collection and presentation. V.C. contributed towards the conceptualisation of idea, crafting methodology and data analysis.

\section{Ethical considerations}

Permission to carry out the study was sought through traditional leadership chiefs, headman and government health officials. Participants completed informed consent forms during interviews and these forms are kept by Dr Matumbu at a secure place in a cabinet locker.

\section{Funding}

The study was funded by the authors.

\section{Data availability statement}

Data sharing is not applicable to this article as no new data were created or analysed in this study.

\section{Disclaimer}

The views and opinions expressed in this article are those of the authors and do not necessarily reflect the official policy or position of any affiliated agency of the authors.

\section{References}

Agha, S., Agha S., Hutchinson P. \& Kusanthan T., 2006, 'The effects of religious affiliation on sexual initiation and condom use in Zambia', Journal of Adolescent Health 38(5), 550-555. https://doi.org/10.1016/j.jadohealth.2005.04.012

Ajuwon, A.J., Brieger W.R., Oladepo O. \& Adeniyi J.D., 1995, 'Indigenous surgical practices in rural South Western Nigeria, implications for disease prevention', Health Education Research 10(3), 379-384. https://doi.org/10.1093/her/ 10.3.379

Asamoah, A.A., 2001, 'Best control of HIV/AIDS among the youth', Ghanaian Chronicle, August 15, p. 5.

Auvert, B., Taljaard D., Lagarde E., Sobngwi-Tambekou J., Sitta R.M. \& Puren, A., 2005, 'Randomized, Controlled Intervention Trial of Male Circumcision for Reduction of HIV Infection Risk: The ANRS 1265 Trial', PLoS Medicine, 2 (11), 298.

Avert, n.d., HIV and AIDS in Zimbabwe, viewed 27 May 2019, from https://www.avert. org/professionals/hiv-around-world/sub-saharan-africa/zimbabwe.

Bailey, R.C. \& Egesah, O., 2006, 'Assessment of clinical and traditional male circumcision services in Bungoma District, Kenya: Complication rates and operational needs', USAID, PSI, AIDSMARK, April, p. 560.

Bailey, R.C., Moses S., Parker C.B., Agot K., Maclean I., Krieger J.N. et al., 2007, 'Male circumcision for HIV prevention in young men in Kisumu, Kenya. A randomised controlled trial', Lancet 369(9562), 643-656. https://doi.org/10.1016/S01406736(07)60312-2

Bell, C.M., 2009, Ritual Theory, Ritual Practice. Oxford: Oxford University Press. 
Bongaarts, J., Reining, P., Way, P. \& Conant, F., 1989, 'The Relationship Between Male Circumcision and HIV Infection in African Populations'. AIDS, 3(6), 373-377.

Boyce, P., Huang Soo Lee, M., Jenkins, C., Mohamed, S., Overs, C., Paiva, V. et al., 2007 'Putting sexuality back into HIV/AIDS', Issues, Theory and Practice. Global Public Health 2(1), 1-34. https://doi.org/10.1080/17441690600899362

Brightman, R., 1995, 'Forget culture-replacement, transcendence, and relexification' Cultural Anthropology 10(4), 509-546. https://doi.org/10.1525/can.1995.10.4. $02 \mathrm{a} 00030$

Caldwell, J.C., Caldwell P. \& Quiggin P., 1997, 'Male Circumcision in Africa from a Regional to a Specific Nigerian Examination', Social Science and Medicine, 44, 1181-1193.

Doyle, D., 2005, Ritual male circumcision: A brief history, College Physicians, Boston, MA.

Dunsmuir, W.D. \& Gordon, E.M., 1999, 'The history of circumcision', BJU International 83(1), 1-12. https://doi.org/10.1046/j.1464-410x.1999.0830s1001.x

Durkheim, E., 1912, The elementary forms of the religious life, The Free Press, New York.

Evans, H.C., 2015, The varemba circumcision tradition in humans, viewed 20 August 2016, from https://www.fair-Planet.org.

Feldman, D.A., 1990, 'Assessing viral, parasitic, and sociocultural cofactors in affecting HIV-1 transmission in Rwanda', in D.A. Feldman (ed.), Culture and AIDS, pp. 45-54, Praeger, New York.

Fink, A., 1986, 'A possible explanation for heterosexual male infection with AIDS', New England Journal of Medicine 315(18), 1167. https://doi.org/10.1056/ NEJM198610303151818

Ford, M., 2006, 'Circumcision significantly reduces HIV and AIDS risk', Ars Technica, viewed 12 July 2017, from http://arstechnica.com/science.

Gausset, Q., 2001, 'AIDS and Cultural Practices in Africa: The Case of the Tonga (Zambia)', Social Science and Medicine, 52(4), 509-518.

Ghebremichael, M., Larsen, U. \& Paintsil, E., 2009, 'Association of age at first sex with HIV-1, HSV-2, and other sexual transmitted infections among women in Northern Tanzania', Sexually Transmitted Diseases 36(9), 570-576. https://doi.org/10.1097/ OLQ.0b013e3181a866b8

Gono, V., 2015, 'Row over modern circumcision vs culture: Traditional leaders mourn death of cultural rite', Sunday, 19 July, viewed 05 February 2014, from https:// www.sundaynews.co.zw/row-over-modern-circumcision-vs-culture-traditionalleaders-mourn-death-of-cultural-rite/.

Granich, R. \& Mermin, J., 2001, HIV health and your community: A guide for action, The Hespenian Foundation, Berkeley, CA.

Gray, P.B., 2004, 'HIV and Islam: Is HIV prevalence lower among Muslims?', Social Science and Medicine 58(9), 1751-1756. https://doi.org/10.1016/S0277-9536 Science and
(03)00367-8

Gray, R.H., Kigozi, G., Serwadda, D., Makumbi, F., Watya, S., Nalugoda, F. et al., 2007, 'Male circumcision for HIV prevention in men in Rakai, Uganda: A randomised trial', Lancet 369(9562), 657-666. https://doi.org/10.1016/S0140-6736(07) trial', Lance

Green, E.C., Zokwe, B. \& Dupree, J.D., 1993, 'Indigenous African healers promote male circumcision for prevent of sexually diseases', Tropical Doctor 23, 182-183. https://doi.org/10.1177/004947559302300423

Greenwald, D.E., 1973, 'Durkheim on society, thought and ritual', Sociological analysis 34(3), 157-168.

Hallett, T.B., Lewis, J., Lopman, B.A. \& Nyamukapa, C., 2007, 'Age at First Sex and HIV Infection in Rural Zimbabwe', Studies in Family Planning, 38(1), 1-10.

Halperin, D.T. \& Bailey, R.C., 1990, 'Male circumcision and HIV infection: 10 years and counting', Lancet 354(9192), 1813-1815. https://doi.org/10.1016/S01406736(99)03421-2

Hardy, D.B., 1987, 'Cultural practices contributing to the transmission of human immunodeficiency virus in Africa. Reviews of infectious diseases', Journal of immunodeficiency virus in Africa.
Religion in Africa 19(2), 99-120.

HIV and AIDS, Zimbabwe, 2013, viewed 24 August 2015, from https://www.medbox. org/zimbabwe-national-hiv-and-aids-estimates.

HIV and AIDS in Zimbabwe, 2017, Global information and education on HIV and AIDS viewed 28 March 2017, from https://www.avert.org/professionals/hiv-aroundworld/sub-saharan-africa/zimbabwe.a.

Kippax, S., Reis, E. \& De Wit, J., 2011, 'Two sides to the prevention coin: Efficacy and effectiveness', AIDS Education and Prevention 23(5), 393-396. https://doi. org/10.1521/aeap.2011.23.5.393

Kebaabetswe, P., Lockman, S., Mogwe, S., Mandevu, R., Thior, I., Essex, M. et al., 'Male circumcision: an acceptable strategy for HIV prevention in Botswana', Sexually transmitted infections 79(3), 214-219.

Koyana, D.S., 1980, Customary law in a changing society, Juta, Johannesburg.

Le Roux, M., 2003, “"The Lemba - A lost tribe of Israel in Southern Africa?" Pretoria: University of South Africa', African Journal of Reproductive Health 11(3), 209-224.

Makuvaza, N., 1996, 'Education in Zimbabwe, Today Tomorrow: the Case for Unhuist/ Ubuntuist in Education in Zimbabwe'. Zimbabwe journal of Educational Research, $8(3), 255-266$.

Malisha, L., Maharaj, P. \& Rogan, M., 2008, 'Rites of passage to adulthood: Traditional initiation schools in the context of HIV/AIDS in the Limpopo Province, South Africa', Health, Risk \& Society 10(6), 585-598. https://doi.org/10.1080/1369857 0802533713

Mandivenga, E., 1989, "The history and "re-conversion" of the VaRemba of Zimbabwe', Journal of Religion in Africa 19(2), 98-124. https://doi.org/10.1163/ $157006689 \times 00134$
Marck, J., 1997, 'Aspects of male circumcision in sub-equatorial African culture history', Health Transition Review 7(Suppl.), 337-360.

Mattson, C.L., Bailey, R.C., Muga, R., Poulussen, R. \& Onyango, T., 2005, 'Acceptability of male circumcision and predictors of circumcision preference among men and women in Nyanza Province, Kenya', AIDS Care 17, 182-194. https://doi.org/10.10 80/09540120512331325671

Meissner, O. \& Buso, D.L., 2007, 'Traditional male circumcision in the Eastern Cape Scourge or blessing?', South Africa Medical Journal 97, 371-373.

Ministry of Health and Child Welfare, 2008, National Health Strategy for Zimbabwe, Harare: Government Printers.

Moses, S.M.M., 2009, 'Male circumcision: A new approach to reducing HIV transmission', Canadian Medical Association Journal 81(8), E134. https://doi. org/10.1503/cmaj.090809

Morris, B.J., 2007, 'Why circumcision is a biomedical imperative for the 21 (st) century', Bioessays, 29(11), 1147-1158.

Moyo, J., 2017, 'Night: Perfect cover for AIDS testing in Zimbabwe', Reuters, viewed 27 May 2019, from https://www.reuters.com/article/zimbabwe-aids-night/nightperfect-cover-for-aids-testing-in-zimbabwe-idUSL2N1MRONP.

Ngalande, R.C., Levy, J., Kapondo C.P.N. \& Bailey, R.C., 2006, 'Acceptability of male circumcision for prevention of HIV infection in Malawi', AIDS and Behavior 10(4), 377-385. https://doi.org/10.1007/s10461-006-9076-8

Niang, I.C. \& Boiro, H., 2007, “'You can also cut my finger!”: Social construction of male circumcision in West Africa, a case study of Senegal and Guinea Bissau', Reproductive Health Matters15, 22-32. https://doi.org/10.1016/S0968-8080(07) 29312-7

Nkwi, P.N., 2005, 'The Impact of Cultural Practices on the Spread of HIV/AIDS: an Anthropological Study of Selected Countries in Sub-Saharan Africa', Discovery and Innovation, 17, 2135

Packard, R.M. \& Epstein, P., 1991, 'Epidemiologists, social scientists, and the structure of medical research on AIDS in Africa', Social Science and Medicine 33(7), 771-783. https://doi.org/10.1016/0277-9536(91)90376-N

Parfitt, T., 2002, 'The Lemba: An African judaising tribe', in T. Parfitt \& E. Trevisan-Sem (eds.), Judaising movements: Studies in the margins of Judaism, pp. 42-43, Routledge, Curzon, London.

Pelzer, K., Niang, C.I., Muula, A.S., Bowa, K., Okeke, L., Boiro, H. et al., 2007, 'Editorial review: Male circumcision, gender and HIV prevention in sub-Saharan Africa: A (social science) research agenda', Journal of Social Aspects of HIV/AIDS 4(3), 658-667. https://doi.org/10.1080/17290376.2007.9724889

Pickering, W.S.F., 1984, Durkheim's sociology of religion: Themes and theories, Routledge, London.

Popovsky, M., 2010, 'Circumcision', in D.A. Leeming, K. Madden \& S. Marlan (eds.), Encyclopedia of Psychology and Religion, Springer, New York, pp. 153-154.

Rennie, S., Muula, A.S. \& Westreich, D., 2007, 'Male circumcision and HIV prevention: Ethical, medical and public health tradeoffs in low-income countries', Global Medical Ethics 33(6), 357-361. https://doi.org/10.1136/jme.2006.019901

Skinner, J., Underwood, C., Schwandt, H. \& Magombo, A., 2013, 'Transitions to adulthood: Examining the influence of initiation rites on the HIV risk of adolescent girls in Mangochi and Thyolo districts of Malawi', Psychological and Socio-medical girls in Mangochi and Thyolo districts of Malawi', Psychological and Socio-medical
Aspects of AIDS/HIV 25(3), 296-301. https://doi.org/10.1080/09540121.2012. Aspects
701721

Shilling, C. \& Mellor, P.A., 1998, 'Durkheim, morality and modernity: Collective effervescence, homo duplex and the sources of moral act', British Journal of Sociology 49(2), 193-209. https://doi.org/10.2307/591309

Sibanda, F., 2013, 'Beyond identity scars: Reflections on the vitality of Shangani male circumcision in the context of HIV and AIDS in Zimbabwe', Journal of Emerging Trends in Educational Research and Policy Studies (JETERAPS) 4(1), 1-7.

Spinelli, E., 1989, The interpreted world: An introduction to phenomenological psychology, Sage, London. Taljaard, R., et al. 2003, 'Potential for an Intervention Based on Male Circumcision in a South African town with high levels of HIV infection'. AIDS Care, 15, 315-327.

Taljaard, R.C., Lagarde, E., Taljaard, D.J., Campbell, C., Macphail, C., Williams, B. et al., 2003, 'Potential for an intervention based on male circumcision in a South African town with high levels of HIV infection', AIDS Care 15, 315-327. https://doi. org/10.1080/0954012031000105379

Taruvinga, M., 2015, 'Male circumcision to save $\$ 1,3 \mathrm{bn}$ ', The Zimbabwe Mail, 02 February, p. 7

Tarimo, E.A.M., Francis, J.M., Kakoko, D., Munseri, P., Bakari, M. \& Sandstrom, E., 2012, 'The perceptions on male circumcision as a preventive measure against HIV infection and considerations in scaling up of the services: a qualitative study among police officers in Dar es Salaam, Tanzania' BMC Public Health 12(1). https://doi.org/10.1186/1471-2458-12-529

Thorlindsson, T. \& Bernburg, J.G., 2004, 'Durkheim's theory of social order and deviance: A multi-level test', European Sociological Review 20(4), 271-285. https://doi.org/10.1093/esr/jch025

Van Gennep, A., 1909, 'Translation: 1960', in The rites of passage, transl. M.B. Vizedom \& G.L. Caffee, The University of Chicago Press, Chicago, IL.

Van Houten, S., 2007, 'An historical analysis of the HIV/AIDS training of health care workers in the Western cape, 1989-2004', PhD thesis, University of Stellenbosch, Cape Town.

Vincent, L., 2008a, “"Boys will be boys": Traditional Xhosa male circumcision, HIV and sexual socialisation in contemporary South Africa', Culture, Health \& Sexuality 10(5), 431-446. https://doi.org/10.1080/13691050701861447 
Vincent, L., 2008b, Male circumcision policy, practices and services in the Eastern Cape Province of South Africa, viewed 04 December 2015, from https://www. malecircumcision.org.

Weiss, H., Quigley, M. \& Hayes, R., 2000, 'Male circumcision and risk of HIV infection in sub-Saharan Africa: A systematic review and meta-analysis', AIDS 14(15), 2361-2370. https://doi.org/10.1097/00002030-200010200-00018

Welbourn, A. \& Hoare, J. 2008. (ed) HIV and AIDS. Oxfam: Oxford. pp xiii -xxiii.

WHO/UNAIDS, 2015, Global AIDS response progress report, viewed 06 November 2016, from www.uniaids.org/sites.
Wikipedia, n.d., Lemba people, viewed 27 May 2019, from https://en.wikipedia.org/ wiki?curid=90774.

World Health Organisation (WHO), 2006, Strategies and approaches for male circumcision programming, WHO meeting report: 5-6 December, Geneva. WHO press.

World Health Organisation (WHO), 2009, Traditional male circumcision among young people: A public health perspective in the context of HIV prevention viewed 27 May 2019, from https://apps.who.int/iris/bitstream/handle/10665/ 44247/9789241598910_eng.pdf;jsessionid=3F8505767EF19E8F39D18089FE308 844 ? sequence $=1$. 